\title{
Study of thrombocytopenia in neonates at a teaching hospital in Telangana
}

\author{
Khetavath G.S ${ }^{1}$, B. Laxmi Narayana², Bingi $\mathbf{K}^{3}$ \\ ${ }^{1}$ Dr. Gopal Singh Khetavath, Assistant Professor, Department of Paediatrics, Government Medical College \\ Nizamabad, Telangana, ${ }^{2}$ Dr. B. Laxmi Narayana, Assistant Professor, Department of Pathology, Kakatiya \\ Medical College, Warangal, ${ }^{3}$ Dr. Koteshwar Bingi, Associate Professor, Department of Pediatrics, Government \\ Medical College, Nizamabad, Telangana, India.
}

Address for Correspondence: Dr. Gopal Singh Khetavath, Assistant Professor, Department of Pediatrics, Government Medical College Nizamabad, Telangana. Email id: resdoc555@gmail.com

\begin{abstract}
Introduction: Thrombocytopenia is a problem frequently encountered in the neonatal period and it is a significant cause of morbidity and mortality in the sick, preterm and full term babies. Thrombocytopenia in neonates needs evaluation. One of the major risk factor associated with decreased platelet count is sepsis. Thrombocytopenia is common in preterm babies. Aim of the study: To study incidence of thrombocytopenia in neonates and identify associated risk factors with the neonatal thrombocytopenia. Material and Methods: Prospective study was done for duration of 1 year i e from March 2016 to February 2017 at Government medical college and Hospital, Nizamabad, Telangana. A total of 120 high risk neonates who were admitted in NICU during this period were included in the study. Results: Among 120 cases, 50 cases (41.6\%) showed Moderate Thrombocytopenia in neonates. About 40 cases $(33.3 \%)$ showed severe thrombocytopenia in neonates. 30 cases $(25 \%)$ showed mild Thrombocytopenia in neonates. $66.5 \%(80 / 120)$ of preterm babies showed lower platelet count Among 120 thrombocytopenic neonates, sepsis was observed in $66.6 \%$. Conclusion: The neonatal thrombocytopenia incidence was $31.5 \%$. There were more premature neonates of thrombocytopenia induced by sepsis.
\end{abstract}

Key words: Neonatal thrombocytopenia, Sepsis, Premature neonates

\section{Introduction}

Thrombocytopenia is one of the common hematological problems encountered in the neonatal period particularly in the sick newborns, premature babies and neonates admitted in neonatal intensive care units and usually indicate an underlying pathologic process. It is a significant cause of morbidity and mortality in the sick preterm and full term infant and accounts up to 20 to $40 \%$ of the newborns admitted to Neonatal Intensive Care Unit (NICU) [1]. Most of the ill and premature infants have low platelet count [1].

Thrombocytopenia is a problem frequently encountered in the neonatal period and it is a significant cause of morbidity and mortality in the

Manuscript received: $7^{\text {th }}$ June 2017

Reviewed: $16^{\text {th }}$ June 2017

Author Corrected: $24^{\text {th }}$ June 2017

Accepted for Publication: $29^{\text {th }}$ June 2017 sick, preterm and full term babies [2]. The frequency of neonatal thrombocytopenia has been estimated to range from 20 to $40 \%$ of the newborns admitted to NICU in different studies [3]. Some patients with bacterial septicemia may develop a coagulopathy associated with disseminated intra vascular coagulation (DIC).

The presence of thrombocytopenia is seen frequently in early sepsis with or without laboratory evidence of overt DIC [4,5]. Thrombocytopenia is defined as platelet count less than $150,000 / \mathrm{uL}$ and platelet count less than $100,000 / \mathrm{uL}$ is considered as definitely abnormal at any gestational age and deserves further evaluation. However, significance of platelet count between 100,000 to $150,000 / \mathrm{uL}$ in neonate is not clear but 
needs further follow-up [6,7,8,]. Further investigations depend upon infant's condition and subsequent platelet count. $[9,10]$

Aim of the study- To study incidence of thrombocytopenia in neonates. To identify associated risk factors with the neonatal thrombocytopenia and clinical impact of thrombocytopenia.

\section{Materials and Methods}

Prospective study was conducted for duration of 1 year i.e. from March 2016 to February 2017 at Government medical college and Hospital, Nizamabad, Telangana. Approval from the institutional ethical committee was obtained.

A total of 120 high risk neonates who were admitted in NICU during this period were included in the study. An informed consent was taken from the parents.

Demographic Data of neonates were included i e, age, sex, gestational age, and birth weight. Information regarding the clinical history of neonate, e.g., sepsis, renal failure, ventilator assistance, birth asphyxia (delayed cry), gastrointestinal problems, and medications were noted.

The maternal data included age, parity, pregnancy related complications, antenatal findings in ultrasound, perinatal events and any other associated illness were included. The data related to transfusion consisted of frequency and volume of transfused platelets or other components. Platelet counts were done on the first, third and fifth day of admission and thereafter every 72 hours till counts were normal.
Blood Samples were collected by a trained technician. Blood Samples were sent to haematology lab. Low counts were collaborated with a peripheral blood smear.

The various grades of thrombocytopenia are: mild (100,000-150,000 per cu mm), moderate $(50,000$ $100,000$ per $\mathrm{cu} \mathrm{mm})$ and severe $(<50,000$ per $\mathrm{cu}$ $\mathrm{mm})$. Some authors categorize platelet counts less than 30,000 per cu $\mathrm{mm}$ as severe thrombocytopenia [11].

Standard guidelines for platelet transfusions were followed for management.

\section{Inclusion Criteria}

- Platelet count of less than $1,50,000 / \mathrm{cu}$ mm was taken for determining thrombocytopenia.

- Babies with neonatal sepsis,

- Babies having significant birth asphyxia (requiring resuscitation for $>30$ seconds),

- Babies with intra-uterine growth restriction (IUGR),

- low birth weight babies (birth weight $<2.5 \mathrm{~kg}$ ),

- Babies born to mothers with a known disorder causing thrombocytopenia, pregnancy induced hypertension, platelet disorders in mother or mothers on drugs causing thrombocytopenia), babies with suspected intrauterine infections.

\section{Exclusion Criteria}

- Babies having thrombocytopenia and died.

- Babies admitted in NICU with normal platelet count.

\section{Results}

About 120 cases of thrombocytopenia were included in the study. The incidence of neonatal thrombocytopenia in this study was $31.5 \%$. Male preponderance was seen with $66.6 \%$ male babies admitted in NICU while female babies were about $33.3 \%$ (table 1$)$

Table-1: Sex-wise distribution of cases

\begin{tabular}{|c|c|c|}
\hline Sex & No. of cases & \% \\
\hline Males & 80 & 66.7 \\
\hline Females & 40 & 33.3 \\
\hline Total & $\mathbf{1 2 0}$ & $\mathbf{1 0 0}$ \\
\hline
\end{tabular}


About 50 cases (41.6\%), showed Moderate Thrombocytopenia in neonates. 40 cases (33.3\%) showed severe Thrombocytopenia in neonates. About 30 cases (25\%) showed mild Thrombocytopenia in neonates. Early onset thrombocytopenia (<3days of age) was seen in 66.6\% (80/120) and late onset thrombocytopenia (3-28 days) in $33.3 \%(40 / 120)$.

$66.5 \%(80 / 120)$ of babies born during less than 36 weeks of gestation showed lower platelet count.

Out of 80 cases born $<36$ weeks, 20 cases with weight is $<1 \mathrm{~kg}$ and 60 cases with $1.5-2.4 \mathrm{~kg}$ weight. Out of 40 cases born during gestational period 36- 38 weeks, 30 cases showed $2.5 \mathrm{~kg}$ and 10 cases $1.5 \mathrm{~kg}$.(Table 2 \&Table 3 ).

Table-2: Platelet count in relation to birth weight of neonates.

\begin{tabular}{|c|c|c|}
\hline Weight in kg & No. of cases & \% \\
\hline$<1 \mathrm{~kg}$ & 20 & 16.7 \\
\hline $1-2.4 \mathrm{~kg}$ & 70 & 58.3 \\
\hline$>2.5 \mathrm{~kg}$ & 30 & 25 \\
\hline Total & $\mathbf{1 2 0}$ & $\mathbf{1 0 0}$ \\
\hline
\end{tabular}

$58.3 \%$ of the neonates weighed between $1-2.4 \mathrm{~kg}$.

Table-3: Platelet count in relation to gestational age

\begin{tabular}{|c|c|c|}
\hline Gestational age & No. of cases & \% \\
\hline Preterm $(<36$ weeks $)$ & 80 & 66.7 \\
\hline Normal gestational age(36-38 weeks ) & 40 & 33.3 \\
\hline Total & $\mathbf{1 2 0}$ & $\mathbf{1 0 0}$ \\
\hline
\end{tabular}

$66.5 \%$ were preterm babies.

Among 120 thrombocytopenic neonates, sepsis was observed in 66.6\% (Table 4). About 40 cases with neonatal thrombocytopenia showed pregnancy induced hypertension in their antenatal history. Present study observed that $33.3 \%$ (40/120) of neonates had history of pregnancy induced hypertension in mothers.

Table-4: Risk factors associated with neonatal thrombocytopenia.

\begin{tabular}{|c|c|c|}
\hline Risk factors & No. of cases & $\%$ \\
\hline Neonatal sepsis & 80 & 66.7 \\
\hline Birth asphyxia & 20 & 16.7 \\
\hline Neonatal respiratory distress syndrome & 20 & 16.6 \\
\hline Total & $\mathbf{1 2 0}$ & $\mathbf{1 0 0}$ \\
\hline
\end{tabular}

\section{Discussion}

A common haematological abnormality encountered in NICU is neonatal thrombocytopenia. There are many predisposing factors for thrombocytopenia and they interact in a complex manner to cause thrombocytopenia.

This study included 120 neonates admitted in NICU. Gupta, et al studied a total of 870 neonates who were admitted in Neonatal Intensive Care Unit (NICU). Out of 870 cases 146 cases showed decreased platelet count [12]. This study showed male preponderance with 80 (66.6\%) males and 40 (33.3\%) females. Anubha Sharma et al study population comprised 84 males and 16 females [13]. Bhat YR et al showed that 57.7\% of thrombocytopenia was associated with the male gender [14]. 
Table-5: Comparative studies showing decreased platelet count.

\begin{tabular}{|c|c|c|}
\hline Platelet count & $\begin{array}{c}\text { No. of cases in Gupta, } \\
\text { et al (12) }\end{array}$ & $\begin{array}{c}\text { No. of cases in } \\
\text { present study }\end{array}$ \\
\hline Mild Thrombocytopenia $(100,000-150,000$ per cu mm) & 70 & 30 \\
\hline Moderate Thrombocytopenia $(50,000-100,000$ per cu mm) & 40 & 50 \\
\hline Severe Thrombocytopenia $(<50,000$ per cumm) & 36 & 40 \\
\hline Total & $\mathbf{1 4 6}$ & $\mathbf{1 2 0}$ \\
\hline
\end{tabular}

In this study $66.7 \%$ of preterm babies developed thrombocytopenia while Beiner ME et al showed that $31 \%$ of preterm babies developed thrombocytopenia [15]. Anubha Sharma et al reported 58.2\% preterm babies developed thrombocytopenia [13].

Thrombocytopenia in neonates is associated with a wide variety of factors, including prematurity and low birth weight, small for gestational age, sepsis, hypotension, necrotizing enterocolitis, asphyxia, thrombi and exchange transfusions [16-19].

According to Western medical literature, prematurity, IUGR and birth asphyxia were the common causes for neonatal thrombocytopenia whereas in our study septicaemia was the common cause [20,21].

In this study thrombocytopenia was observed in $58.3 \%$ in low birth weight babies of weight being $1.5-2.4 \mathrm{~kg}$ and $16.6 \%$ of the extremely low birth weight (ELBW) population Christensen RD et al observed thrombocytopenia in $73 \%$ of the extremely low birth weight (ELBW) population, being more common in the neonates with birth weight $<800 \mathrm{~g}$ [22].

Thrombocytopenia was observed in $66.6 \%$ of septic neonates while Gupta AK et al observed that $81.5 \%$ of septic neonates developed thrombocytopenia [23]. Of these thrombocytopenic neonates, 16.6\% had respiratory risk factors. Gupta AK et al observed that $43 \%$ of thrombocytopenic neonates had respiratory risk factor [23].

The mechanism by which septicemia leads to thrombocytopenia is by decreased platelet production as well as increased platelet consumption and sequestration in the enlarged spleen usually resulting in severe thrombocytopenia. This difference may be due to the higher incidence of septicemia in our extramural admissions which warrants the need for strict aseptic precautions while conducting deliveries as well as in handling the newborn babies. Sepsis also causes DIC, immune-mediated destruction and decreased production of platelets from infected marrow [24].

$33.3 \%$ of neonates had history of pregnancy induced hypertension in mothers. Bhat YR et al observed that $36 \%$ of neonates born to mothers with Pregnancy induced hypertension had thrombocytopenia [14].

Although not much studies on platelet count in sepsis, yet it has well been described for more than 40 years that patients with sepsis often have thrombocytopenia and the intravenous injection of lipopolysaccharides in mice induce rapid thrombocytopenia. All sepsis agents can cause thrombocytopenia in new born. Platelets are believed to be active participants in host defence. Diffuse endothelial cell trauma, bacterial, fungal toxins, increased platelet activation and increased platelet consumption due to DIC are among the factors that play a role in the mechanism of thrombocytopenia. Lipopolysaccharide, which is a component of cell wall of gram negative organisms, leads to thrombocytopenia. Lipid - A, a component of lipopolysaccharide, increases the consumption [25].

\section{Conclusion}

The incidence of neonatal thrombocytopenia in this study was $31.5 \%$. There were more premature infants than term infants of thrombocytopenia

induced by sepsis. The common causes of the neonatal thrombocytopenia were: Sepsis, neonatal respiratory distress syndrome, asphyxia. 
It is therefore important to identify infants at risk, and if needed, initiate transfusion therapy to prevent severe bleeding and potentially significant morbidity.

Funding: Nil, Conflict of interest: None initiated, Perission from IRB: Yes

\section{References}

1. Kaplan C, Morel kopp MC, Clemenceau S. Fetal and neonatal alloimmune thrombocytopenia. Transf Med. 1992;2:265-271.

2. Murray NA, Roberts IA. Circulating megakaryocytes and their progenitors in early thrombocytopenia in preterm neonates. Pediatr Res. $1996 \mathrm{Jul} ; 40(1): 112-9$.

3. Bussel JB, Zabusky MR, Berkowitz RL, McFarland JG. Fetal alloimmune thrombocytopenia. N Engl J Med. 1997 Jul 3; 337 (1): 22-6.

4. Corrigan JJ, Jr, Ray WL, May N. Changes in blood coagulation system associated with septicemia. NEnglJMed. 1968;279:851.

5. Neame PB, Kelton JG, Walker IR, Stewart IO, Nossel HL, Hirsh J. Thrombocytopenia in septicemia: the role of disseminated intravascular coagulation. Blood. 1980 Jul;56(1):88-92.

6. Aballi AJ, Puapondh Y, Desposito F. Platelet counts in thriving premature infants. Pediatrics. 1968 Oct; 42(4):685-9.

7. Burrows RF, Kelton JG. Fetal thrombocytopenia and its relation to maternal thrombocytopenia. N Engl J Med. 1993 Nov 11;329(20):1463-6.

8.Radley JM, Scurrfield G. Mechanism of platelet release. Blood 1980, 56: 996.

9. Van den Hof MC, Nicolaides KH. Platelet count in normal, small, and anemic fetuses. Am J Obstet Gynecol. 1990 Mar;162(3):735-9.

10. Burrows RF, Kelton JG. Thrombocytopenia at delivery: a prospective survey of 6715 deliveries. Am J Obstet Gynecol. 1990 Mar;162(3):731-4.

11. Groves A, Kuschel C. NW Newborn Clinical Guideline: Neonatal Thrombocytopenia.
12. Anil K. Gupta, Sudarshan Kumari, Abhishek Singhal, and Aruna Bahl Neonatal thrombocytopenia and platelets transfusion. Asian journal of transfusion science Asian J Transfus Sci. 2012 Jul-Dec; 6(2): 161-164.

13. Anubha Sharma1, Karuna Thapar. A prospective observational study of thrombocytopenia in high risk neonatesin a tertiary care teaching hospital,Sri Lanka Journal of Child Health, 2015: 44(4): 213-219.

14. Bhat YR, Cherian CS. Neonatal thrombocytopenia associated with maternal pregnancy induced hypertension. Indian J Pediatr. 2008 Jun;75(6):571-3. doi: 10.1007/s12098-0080110-x. Epub 2008 Aug 31.

15. Beiner ME, Simchen MJ, Sivan E, Chetrit A, Kuint J, Schiff E. Risk factors for neonatal thrombocytopenia in preterm infants. Am J Perinatol. 2003 Jan;20(1):49-54.

16. Roberts I, Stanworth S, Murray NA. Thrombocytopenia in the neonate. Blood Rev. 2008 Jul;22 (4):173-86. doi: 10.1016/j.blre.2008. 03.004. Epub 2008 Apr 22.

17. Christensen RD. Advances and controversies in neonatal ICU platelet transfusion practice. Adv Pediatr. 2008; 55:255-69.

18. Het Kwaliteitsinstituut voor de Gezondheidszorg CBO: CBO-richtlijn bloedtransfusies. Alphen aan den Rijn, Van Zuiden Communications B.V 2004, 247-257.

19. Bonifacio L, Petrova A, Nanjundaswamy S, Mehta R. Thrombocytopenia related neonatal outcome in preterms. Indian J Pediatr. 2007 Mar;74 (3): 269-74.

20. Andrew M, Castle V, Saigal S, Carter C, Kelton JG. Clinical impact of neonatal thrombocytopenia. J Pediatr. 1987 Mar;110(3): 457-64.

21. I Roberts and N Murray, Neonatal thrombocytopenia: causes and management, Arch Dis Child Fetal Neonatal Ed. 2003 Sep; 88(5): F359-F364. 
22. Christensen RD, Henry E, Wiedmeier SE, Stoddard RA, Sola-Visner MC, Lambert DK, Kiehn TI, Ainsworth S. Thrombocytopenia among extremely low birth weight neonates: data from a multihospital healthcare system. J Perinatol. 2006 Jun;26(6):348-53.

23. Gupta AK, Kumari S, Singhal A, Bahl A. Neonatal thrombocytopenia and platelets transfusion. Asian J Transfus Sci. 2012 Jul;6 (2): 161-4. doi: 10.4103/0973-6247.98924.
24. Zipursky A, Palko J, milner $\mathrm{R}$ et al. The haematology of bacterial infections in premature infants. Pediatrics, 1976; 57:838- 41.

25. Parvez Ahmad, Rajnesh Kaith, Imran Gattoo, Bilal Ahmad Najar, Sheikh Quyoom Hussain. Thrombocytopenia as A Predictor of Neonatal Sepsis in Very Low Birth Weight Babies and Its Correlation with Specific Organism Involved: A Hospital Based Observational Study.Indian Journal of Neonatal Medicine and Research. 2015 Jul, Vol3 (3): $7-13$

\section{How to cite this article?}

Khetavath G.S, B. Laxmi Narayana, Bingi K. Study of thrombocytopenia in neonates at a teaching hospital in Telangana. J PediatrRes.2017;4(06):416-421.doi:10.17511/ijpr.2017.i06.11. 